\title{
CURRENT DEVELOPMENTS IN PETROLEUM INCOME TAXATION
}

\author{
DONALD H. WATKINS*
}

This paper examines the recent changes in federal oil and gas income tax. ation resulting from the April 21, 1980 Federal Ways and Means Motion, as well as developments in Revenue Canada policies and case jurisprudence. The provisions of the new Alberta Corporate Income Tax Act are also scrutinized, along with proposals for a new Canada-U.S. tax convention.

There have been a number of developments in the area of energy taxation during the past year. Two of these, the introduction into Parliament of the federal Ways and Means Motion of April 21, 1980 and the enactment by the Alberta Legislature of The Alberta Corporate Income Tax Act, have arisen during the past few months. This paper will examine certain portions of these documents and will also review developments within the past year in respect of the relevant case jurisprudence and energy taxation policies of The Department of National Revenue.

In addition, the governments of Canada and the United States of America have agreed upon a new income tax convention. Although a draft of the new treaty was not available at the time of writing, the paper will outline certain of the proposed terms of the treaty as described in press releases issued by the Canadian and U.S. governments.

References herein to "the federal Act" or "ITA" are references to the Income Tax Act, R.S.C. 1952, c. 148, as amended; references to "ITR" are references to the Income Tax Regulations promulgated under the federal Act; references to "ACITA" are references to The Alberta Corporate Income Tax Act, S.A. 1980, c. 10.

\section{PROPOSALS CONTAINED IN THE APRLL 21, 1980 WAYS AND MEANS MOTION (THE “MOTION")}

On April 21, 1980, the Minister of Finance, The Honourable Allan MacEachen, delivered a "Fiscal and Economic Statement" to members of the House of Commons during the course of debate on the Speech from the Throne for the purpose of resolving "the uncertainty with respect to outstanding tax measures and to inform this House of the government's fiscal situation". At the same time, the Minister tabled a Notice of Ways and Means Motion to amend the federal Act which reintroduced, in varying degrees of modification, the proposals contained in the Progressive Conservative government's Ways and Means Motion of December 11, 1979. All Resolutions affecting energy taxation were introduced in the same or in an altered form. Many of the proposals have been designed to eliminate abuses in the tax system, while others amount to a change in fiscal policy.

\section{A. Resolution 28: Write-off of Canadian Oil and Gas Properties}

That costs incurred after December 11, 1979, other than those incurred pursuant to an agreement in writing entered into on or before that date, on the acquisition of Canedian oil and gas properties be deductible at a maximum rate of $10 \%$ per annum on a reducing balance basis.

Under current law, costs incurred after May 6, 1974 by a taxpayer in respect of a Canadian resource property are characterized as a "Canadian development expense"

\footnotetext{
- Partner, Macleod Dixon, Calgary, Alberta.
} 
("CDE") and, together with other outlays and expenses also characterized as CDE, form a positive adjustment or addition to the taxpayer's "cumulative Canadian development expense" ("CCDE pool")!' All tarpayers, whether individuals or corporations and whether or not resident in Canada, may amortize the year-end balance of their CCDE pool at a declining balance rate not exceeding $30 \% .^{2}$ A "Canadian resource property" is defined as a property acquired by the tarpayer after 1971 that is:"

(a) any right, licence or privilege to explore for, drill for, take or store underground petro. leum, natural gas or other related hydrocarbons in Canada;

(b) any right, licence or privilege to prospect, explore, drill, or mine for, minerals in a mineral resource in Caneda;

(c) any oil or gas well situated in Canada;

(d) any rental or royalty computed by reference to the amount or value of production from an oil or gas well, or a mineral resource, situated in Cansda;

(e) any Cansdian real property the principal value of which depends upon its mineral resource content; and

(f) any right to or interest in any of the above described types of property other than property of a trust but including rights to receive procods of disposition in respect thereof.

Resolution 28 of the Motion proposes to reduce the rate of amortization in respect of costs incurred after December 11, 1979 on the acquisition of Canadian oil and gas properties to $10 \%$ per annum on a declining balance basis. A "Canadian oil and gas property" is not defined in the Resolution but it is understood that it will be described in the legislation by cross-references to the definition of "Canadian resource property" 80 as to in. clude properties described in (a) and (c) above and the properties described in (d), (e) and (f) which relate to oil and gas properties situated in Canada. Although the Resolution speaks of costs incurred after December 11, 1979 on the acquisition of Canadian oil and gas properties, implying perhaps that it is not necessary that the property have been acquired after December 11 , in fact it is understood that the proposal will apply only to costs of properties acquired after that date, subject to the grandfather clause (which was not provided for in the form of the original Resolution in the December 11, 1979 Motion).

The Supplementary Information to the Motion indicates that costs of post-December 11, 1979 properties will be included in a separate cumulative account which will operate in a manner similar to the CCDE pool and the "cumulative Canadian exploration expense" account ("CCED pool"). It is understood that such a cost will be referred ta as a "Canadian oil and gas property expense" and the new cumulative account will be referred to as the "cumulative Canadian oil and gas property expense" account. Both will be found in a new section 66.4 of the federal Act. The Supplementary Information indicates that costs of post-December 11, 1979 properties will be added to the new account, that proceeds from the disposition of such properties will reduce the account, and that any positive balance of the account at the end of the taxpayer's taxation year will be deductible by him at a rate of up to $10 \%$ of the positive balance with the amount of the deduction reducing the opening balance for the next taxation year. The $10 \%$ declining balance rate will apply to all taxpayers regardless of residence or corporate or non-corporate status.

Where proceeds of disposition of post-December 11, 1979 properties would operate to reduce the Canadian oil and gas property expense account by an amount greater than the opening balance in the account at the beginning of the taration year plus all additions to the account during the year, the Supplementary Information indicates that a special rule will require the tarpayer to effectively transfer what would otherwise be the year-end negative balance of the account to his CCDE pool as a negative adjustment to that pool, bence reducing any positive balance in that pool otherwise deductible at up to $30 \%$. Any

1. Income Tax Act, R.S.C. 1952, c. 148, as amended, s3. 66.2(5)(a)(iii), 66.2(5)(b)(i) (hereinafter referred to as "ITA").

2. Id. s. $66.2(2)$.

3. Id. $8.66(15)(c)$. 
negative balance of the CCDE pool at the end of the year, taking into account this adjustment, would, as at present, be required to be included in income.

The results of the creation of this new cumulative account would appear to include the following:

(a) While the measure would operate to reduce the rate of deduction for Canadian oil and gas properties, by preserving any rate of deduction the system retains the right to tax proceeds on a disposition, subject to the taxpayer's ability to shelter proceeds, (i) through existing unamortized balances in the new pool, (ii) through acquisitions of Canadian oil and gas properties within the same taxation year, which would operate as a positive adjustment to the pool offsetting the negative adjustment caused by the disposition, and (iii), by the transfer of what would otherwise be a negative balance of the pool to the negative side of the CCDE pool, through the use of undeducted balances in the CCDE pool at the end of the year. This last amount would include development drilling and mining expenses incurred prior to the end of the taration year in which the disposition occurs, costs incurred prior to the end of that year in respect of Cansdian resource properties not qualifying as Canadian oil and gas properties (i.e. costs of mineral resource properties), and costs of Canadian oil and gas properties incurred prior to December 12, 1979.

(b) As noted in (a) above, a tarpayer disposing of a Canadian oil and gas property may effectively charge against the proceeds of disposition any costs of Canadian oil and gas properties, plus costs of other Canadian resource properties that are not oil and gas properties and that are incurred before or after the December 11 date, plus other expenses qualifying as CDE regardless of when incurred, plus costs of Canadian resource properties that are oil or gas properties and that were acquired prior to December 12, 1979. Such a taxpayer will effectively be subject to the same treatment as under the existing system. If, however, the taxpayer disposes of a Canadian resource property that is an oil or gas property acquired prior to December 12, 1979 (or a Canadian resource property that is a mineral resource property, regardless of when it was acquired), the disposition will operate as a negative adjustment to his CCDE pool and any negative balance in that pool will not be subject to reduction by any unamortized balance in the new cumulative Canadian oil and gas property expense pool (except by way of the $10 \%$ deduction). Hence, a tarpayer who disposes of a "pre-December 12, 1979" oil or gas property cannot fully offset the proceeds of disposition through the acquisition of a post-December 11, 1979 oil or gas property within the same taxation year. Exchanges of properties or sales of properties and acquisitions of properties in the same taration year will result in a net tax cost where the acquisition and disposition do not enter into the calculation of the same pool. In cases where a working interest owned on December 11, 1979 is exchanged for a royalty interest on the same property, closer attention may be given to the question of whether the "reservation" of the royalty interest effectively operates as a true reservation such that there has been only a disposition of a property burdened by the reserved interest, or whether the true effect is that there has not been a reservation but rather the granting or disposition of a working interest followed by an acquisition of a royalty interest, in which case the problem will arise as the royalty will be a post-December 11, 1979 oil and gas property. When both properties are post-December 11 properties, such exchanges will continue to be available on a tax-free basis where the amounts are equal as both properties will wash through the same account.

As of June, 1980 the Departinent of Finance was considering a provision whereby a taxpayer who disposes of a Canadian resource property owned on December 11, 1979 that was an oil or gas property would credit the proceeds of disposition to, and operate as a negative adjustment of, the taxpayer's cumulative Canadian oil and gas property expense. Accordingly, a tarpayer could dispose of an "old" property and offset the proceeds 
through an acquisition in the same year of a new property. To the extent the new pool would otherwise go negative, as noted above the otberwise negative balance would be transferred to and operate as a negative adjustment of the taxpayer's CCDE pool allowing him, as at present, to offset any positive balance in that pool against any remaining proceeds. The rule was to be a transitional rule to operate only for dispositions of "old" properties made before 1982.

As of the date of writing, the Department of Finance has reconsidered its position in respect of the 1982 sunset date and it appears that the rule described in the preceding paragraph will be effective for all taxation years ending after December 11, 1979. Accordingly, exchanges or pooling of oil or gas properties will continue to wash through the same account as under the existing regime subject to a negative adjustment to the development expense account where the new account would otherwise become negative.

The proposal in Resolution 28 will not result in the same treatment for Canadian oil and gas property expenses as is now provided under the federal Act in respect of foreign exploration and development expenses. Subsection 66(4) allows a taxpayer resident in Canada to deduct in a taxation year up to $10 \%$ of the foreign exploration and development expenses incurred by him and not previously deductible but the deduction may be increased up to the amount of his resource income from foreign production and foreign royalties plus his proceeds of disposition of foreign resource properties. Resolution 28 would allow the deduction of Canadian oil and gas property expenses against proceeds of disposition of same (or against a negative balance in the CCDE pool if the proposal described in the preceding paragraph is enacted) but otherwise the deduction is limited to $10 \%$ of the unamortized balance. It is ironic that the incentive scheme of the oil and gas provisions of the federal Act will, to this extent, result in foreign resource expenditures being treated on a more favourable basis.

The effect of Resolution 28 relates to more than just the reduction of the deductibility of acquisition costs of oil and gas properties. Under current law, a taxpayer can effectively transfer on a tax-free besis oil and gas properties to a partnership of which he is or becomes a member without resort to the rollover provisions of subsection 97(2) of the federal Act. This may be desirable where not all of the members of the partnership are resident in Cansda, a condition precedent to the operation of the rules in that subsection. In the absence of the rollover provision, subsection 97(1) of the federal Act provides that the taxpayer transferring the property to the partnership is deemed to have disposed of the property for proceeds of disposition equal to the fair market value of the property and the partnership is deemed to have acquired the property at a cost equal to that fair market value. By allocating the cost, which under current law would qualify as a $C D E$, to the transferring partner, the partner has an equal positive and negative adjustment to his CCDE pool effectively resulting in a wash transaction.

The creation of the cumulative Canadian oil and gas property expense account would appear at the outset to eliminate the ability to do the transfer on a tax-free basis where the property to be transferred is a pre-December 12, 1979 property. The disposition by the transferring taxpayer would result in a negative adjustment to his CCDE pool while the deemed acquisition cost to the partnership under subsection 97(1) of the Act would constitute a Canadian oil and gas property expense as the property was acquired by the partnership after December 11, 1979. Accordingly, the allocation of this cost to the transferring partner operates as a positive adjustment to his cumulative Canadian oil and gas property expense account resulting in a $10 \%$ deduction versus a $100 \%$ reduction in his CCDE pool.

The Department of Finance has, however, informally indicated that rules will be pro. vided in the resulting legislation which will operate to treat the property acquired from

4. Id. ss. 66.2(5)(a)(iii) and (iv): 66.2(5)(b)(i) and (v). This assumes the partner is a member of the partnership at the end of the fiscal period of the partnership. Consideration should be given to s. 10:3 of ITA in connec. tion with any type of dispropurtiunate allocation of custs within a partnership. 
the transferring partner as an "old" property to the partnership and the cost as a CDE where the property was owned by the transferring partner on December 11, 1979 so that the allocation of the cost to the partner operates as a positive adjustment to his CCDE pool resulting in a wash transaction. This problem would appear to have been resolved under the proposal described above.

The Department has also indicated that the same concept will apply where a partner. ship conveys "old" oil and gas properties to a partner otherwise than on a termination of the partnership, in which case subsection $98(3)$ or (5) of the federal Act may provide a tax-free rollover. In the absence of these provisions, subsection $98(1)$ provides for a deemed disposition by the partnership and a deemed acquisition by the transferee partner, both at fair market value. As with transfers to the partnership, oil and gas properties owned by the partnership on December 11, 1979 and conveyed by the partnership to a partner will be treated as a property owned by the partner on December 11, 1979; and the allocation of the proceeds of disposition to the partner will result in a negative adjustment to his CCDE pool which, because the property will be treated as a pre-December 11 property, will be adjusted positively in an equal amount.s In this situation, however, there is a further requirement that the partner must have been a member of the partnership on December 11, 1979.

It would appear that the tax-free movement of properties in and out of a partnership will continue to be available for properties already within the transferor's Canadian oil and gas property expense account.

The Supplementary Information indicates that the deduction in respect of the cumulative Canadian oil and gas property expense account will be claimed by the taxpayer after the resource allowance and before depletion allowance. This is of some note as the original December 11, 1979 proposal would have required the deduction claimed to operate as a reduction of the tarpayer's "resource profits" for resource allowance purposes."

Although not indicated in the Motion or in the Supplementary Information, the Department of Finance has verbally indicated that the requisite amendments will be made to the other sections of the federal Act and the regulations thereunder relating to oil and ges property interests. These would include amendments to the joint exploration corporation provisions' and the partnership provisions to provide, respectively, for the renunciation of Canadian oil and ges property expenses by a joint exploration corporation and the flow through of such expenses to members of a partnership. The expenses-for-shares concept presently applicable to acquisition costs of Canadian resource properties will also be applicable to Canadian oil and gas properties acquired after December 11, $1979 . .^{\circ}$

Prior to the December 11, 1979 budget, there were rumours to the effect that the government proposed to totally eliminate the $30 \%$ deduction for acquisition costs of Canedian oil and gas properties. This would presumably have also required the government to eliminate the recognition of income on the disposition of such a property which likely was considered to result in too great a cost to the fisc in view of the rising value of such properties. By structuring the treatment of Canadian oil and gas properties as indicated above, the government has achieved its goal of reducing the deduction available on the acquisition of such properties while retaining its right of full taration on disposition. A real effect of the proposal may be to increase the competitive position of large corporations having large unamortized balances in their CCDE and CCEE pools such that the

6. Id. s8. 66.2(5)(b)(v) and 66.2(6) operate to allocate proceeds of disposition of Canadian resuurce properties to the members of a partnership so that the proceeds roduce the partners' CCDE puols. Without the propused treatment by the Department of Finance, the pruceeds of dispusition of pre-December 11 properties wuuld credit the partner's CCDE account and the acquisition cust would debit his Canadian oil and gas property expense account.

6. See the Supplementary Information to the December 11. 1979 budget and Incume Tax Regulations. ss. $1204(1)$ and $1210(1)$ (hereinafter reforred to as "ITR").

7. ITA. s. 66(10.2).

8. Id., 8. 66.2(5)(a)(v). 
cost of the loss of the twenty percentage points of deduction resulting from the proposed amendment is less than the cost to a purchaser who is in or close to being in a tarable position. This latter group of taxpayers will obviously be examining farmins as another method of acquiring properties; but in this regard, caution must prevail in structuring farmout agreements in view of the policy of the Department of National Revenue in respect of "wide-spread" farmins as outlined by the Department during the past year, as discussed below.

\section{B. Resolution 44: Canadian Resource Properties of Non-residents}

That

(a) all income from the exploitation, holding or disposition of Canedian resource properties of a non-resident who carries on a resource business in Canada after December 11, 1979, be treated as business income subject to tax under Part I of the Act, and

(b) where a non-resident person ceases to carry on a resource business through a fixed place of business in Canada at any time after December 11, 1979, his taxation year shall be deemed to end at that time and, for the purposes only of calculating his income, he or any partnership of which he continues to be a member shall be deemed to have disposed, immediately before the end of that year, of any Canadian resource properties owned immediately after that time at their fair market value and to have reacquired them at that value immediately after the end of the year.

This Resolution is aimed directly at the prevention of a method by which residents or corporations of foreign countries, most commonly residents or corporations of the United States of America, were able to dispose of Canadian resource properties on a tax-free basis. This was accomplished through the conversion of working interests to a royalty and through the use of treaty provisions similar to Articles I and VIII of the Canada-U.S. Tax Convention. It was also possible for such non-residents to retain relatively the same economic interest and cash flow from a resource property but subject themselves to taxation at withholding tax rates rather than the full rates of tax, which include branch tax in the case of corporations. Under subparagraph 115(1)(a)(iii.1) of the federal Act, a non-resident is treated in the same manner as a Canadian resident in respect of a disposition of a Canadian resource property: to the extent the CCDE pool becomes negative, the negative balance is included in income subject to reduction by other available deductions such as the balance of the CCEE pool, earned depletion, etc. The net income is subject to full taration which, in the case of a corporation, would be at rates of 47-51\%, depending on the allocation of income between the provinces and their applicable rates of tax. The tarable income less federal and provincial tax payable thereon is also subject to the branch tax under subsection $219(1)$ to the extent not reinvested in qualifying property. ${ }^{10}$

To avoid the above result, in the case of a disposition of a working interest, the non-resident could convert his working interest to a royalty interest by selling the working interest to a purchaser for a cash payment subject to the reservation by the non-resident of a gross overriding royalty equal in value to the difference between the value of the working interest sold and the cash payment received. Regardless of whether the transaction was treated as a disposition of one resource property and the acquisition of another (in which case there would be adjustments to both the positive and negative side of the CCDE pool with a net negative adjustment equal to the cash paid) or as the disposition of a working interest burdened by a royalty (a negative adjustment only to the CCDE pool equal in value to the cash), the result was a reduction in the CCDE pool

9. Presumably the same rules will apply to the Canadian wil and gas property expense provl in respect of post-December 11. 1979 properties.

10. The rate of branch tax is $25 \%$, except where Canada has a treaty with the country in which the nun-resident is resident and the treaty specifically restricts the branch tax to a rate under $25^{\circ}$, or. where there is no such restriction, the treaty restricts the Canadian withhulding tax on dividends paid to a resident of that cuuntry to a tate under $25^{\circ} \%$, in which latter case the branch tax rate is restricted to that rate. See s. $11(4)$ of the Income Tax Application Rules. 19i1. 
equal to the cash. Usually this net negative adjustment was designed to equal the balance of the non-resident's CCDE and CCEE pools prior to the transaction so that the cash was received free of Canadian tar.

Article I of the present Canada-U.S. Tax Convention prevents the taxation by Canada of industrial and commercial profits of a U.S. enterprise not allocable to a permanent establishment in Canada, and Article VIII protects from Canadian taxation gains derived from the sale or exchange of assets by a resident or corporation or other entity of the U.S. if that entity has no permanent establishment in Canada." As the royalty was structured so as not to give the holder an interest in the oil or gas wells or otherwise constitute the carrying on of a business in Canada by the holder, it did not create a "permanent estab. lishment" in Canada under the definition in the Protocol to the treaty. The non-resident would then dispose of the royalty to a purchaser and, where the non-resident was an entity or corporation of the United States, it would take the position that the disposition of the royalty was protected from Canadian taxation under the treaty either through Article VIII or Article I thereof. The sale of the royalty took place in the next taration year because the definition of "permanent establishment" in the Protocol was to the effect that use by the U.S. entity of "substantial equipment or machinery" in Canada at any time in the taration year would give the entity a permanent establishment in Canada "for such taxable year" - apparently meaning the whole of the year. The time delay also amounted to an attempt to allow the U.S. resident to bolster its position that the royalty was a "capital asset" subject to Article VIII protection. ${ }^{12}$

Resolution 44(b) will trigger a deemed realization of the non-resident when the working interest is converted to a royalty. Specifically, when the non-resident ceases to carry on a resource business in Canada through a fixed place of business, which will presumably occur if all of the working interest holdings owned by him in Canada are converted to a royalty, his taration year will be deemed to end at that time and he will be deemed to have disposed, immediately prior to the year-end, of all Canadian resource properties owned by him immediately after the year-end at their fair market value and to have reacquired them at that value immediately after the year-end. The deemed realization accordingly takes place just prior to the cessation of carrying on business and is a disposition of resource properties owned just after the cessation of business.

For example, where a non-resident disposes of a Canadian oil and gas working interest acquired by him after December 11, 1979 and having a value of $\$ 100$ in return for $\$ 20$ cash and a royalty interest having a value of $\mathbf{3 8 0}$, the analysis would be as follows. At the time of the transaction, if the non-resident owns no other properties in Canada the ownership of which would constitute the carrying on by him of a resource business in Canada through a fired place of business after the transaction, the sale of the working interest will constitute the cessation by him of the carrying on of a resource business in

11. Article I and VIII read as follows:

Article I: -An enterprise of one of the contracting States is not subject to taxation by the other contracting State in respect of its industrial and commercial profits except in respect of such profits allocable in accurdance with the Articies of this Convention to its permanent establishment in the latter State.

No account shall be taken in determining the tax in one of the contracting States, of the mere purchase of merchandise effected therein by an enterprise of the orher State."

Article VIII: "Gains derived in une of the contracting States from the sale or exchange of capital assets by a resident or a corporation or other entity of the other contracting State shall be exempt from taxation in the former State. provided such resident or corporation or other entity has no permanent establishment in the former State."

12. For U.S. tax purpuses, the sale of the working interest and reservation of the royalty was treated as a capital gain subject to a reserve in respect of the royalty which was treated like a morrage. The gain in the year of sale and the portion of each annual payment under the ruyalty which was considered to be a payment of principal under the mortgage were taxed as capital gains at the rate of approximately 28 '. . The "interest" factor was taxed as ordinary income. The 15', Canadian withholding tax on the royalty was credited against the U.S. tax payable. The sale of the royalty triggered a capital gain tax of approximately 28 ' on the pro. ceeds such that the wtal tax paid un the gain was 28', instead of the 54.9', Canadian tax (including branch tax). 
Canada and will end his tacation year. ${ }^{13}$ At the time of the transaction, the non-resident will have a negative adjustment to his cumulative Canadian oil and gas property expense of $\$ 100$ (being the value of the royalty and the cash which are the proceeds of disposition) and a positive adjustment thereto of $\$ 80$ (being the acquisition cost of the royalty - the value of the working interest less the cash)" leaving a net reduction of $\$ 20$. In addition, immediately prior to the deemed taration year-end, the non-resident will be deemed to have disposed of the royalty (the resource property owned by him immediately after the transection) for proceeds of disposition equal to its fair market value $-\mathbf{3 8 0}$. Hence, the account has in the same taration year an additional negative adjustment of $\$ 80$ such that the full $\$ 100$, the value of the working interest, has been credited to the account as a negative adjustment in the taxation year in which the transaction takes place.

If the non-resident converts a working interest to a royalty but continues to carry on a resource business in Canada, the deemed realization rule will not apply. However, Resolution 44(a) proposes to tax the income from the holding of a Canadian resource property as business income not subject to withholding tax. This is an apparent attempt to prevent non-residents from reducing the rate of tax on Canadian business interests by conversion of same to a royalty or other resource interest, the income of which is presently subject to withholding tar. This proposal will apply only where the non-resident is continuing to carry on a resource business in Canada. A non-resident who ceases to carry on a resource business by conversion of business interests to passive resource property interests will be subject to the deemed realization under the proposal in Resolution 44(b) but will be subject only to withholding tax on income from the passive interests. A non-resident who avoids the rule in Resolution 44(b) by ensuring he continues to carry on a resource business in Canada will face income taxation at normal Part I rates (plus branch tax in the case of a corporation) in respect of income from the holding of the resource property and will be subject to the deemed realization rule in either of 44 (a) or 44(b) on ceasing to carry on that business.

It is likely that Resolution 44(a) could withstand the protective provisions of the present tax treaty. Article XI of the existing Canada-U.S. treaty restricts the rate of tax on unearned income to $15 \%$ but applies only if the resident of the Contracting State, i.e. the United States, has no permanent establishment in Canada. Resolution 44(a) applies where the non-resident carries on a business in Canada, which will likely give him a permanent establishment in Canada. It is noteworthy that Resolution 44(b) refers to "ceasing to carry on a resource business through a fixed place of business in Canada" whereas Resolution 44(a) does not refer to a fixed place of business. This makes it difficult for a non-resident to avoid the deemed realization in Resolution 44(b) by continuing to carry on business and then claiming that income from any royalty interest held by him is subject to protection by a provision such as Article XI: the requirement in that provision that there be no permanent establishment in Canada will almost surely necessitate the removal of any fixed place of business in Canada, which will raise the spectre of the 44(b) deemed realization. ${ }^{15}$ In any event, as noted below, the new Canada-U.S. tax convention proposes to allow each country to tax, as business income, income from natural resource royalties on property situated in that country.

Resolution 44(a) applies after December 11, 1979 to any non-resident who carries on a resource business in Canada. Hence, any non-resident carrying on business in Canada on December 12, 1979 and holding a royalty interest which did not form part of that business and was subject to withholding tax only will suddenly find himself subject to tax under Part I of the federal Act on income earned from the royalty after December 11 , 1979.

13. Presumably, the taxation year ends just after the transaction so it is taxed in the same year as the deemed disposition.

14. The D'Auteuil Lumber Co. Ltd. v. M.N.R. (1970) 24 DTC 6096 (Exchequer Court).

15. The definition of "permanent establishment" in the Protocol to the present Canada-U.S. Convention includes a reference to a "fixed place of business" of the resident. 
An actual or deemed disposition by a non-resident partner of his interest in the partnership will not trigger the rule in Resolution 44(b), although this appeared to be a result of the original wording of the December 11, 1979 Ways and Means Motion. The reference to "any partnership of which he continues to be a member" is an attempt to realize income in the partnership and hence to all the non-resident partners when there is a termination by the partnership of the carrying on of a resource business through a fixed place of business in Cansda. As members of a partnership are considered to carry on the business carried on by the partnership, where the partnership ceases to carry on business so does the partner and the rule will apply to trigger income to the partnership. If a partnership is composed of resident partners and non-resident partners, the rule in 44 (b) would apply only for the purpose of calculating the income of the non-residents. The partnership will have the deemed disposition but the proceeds of the disposition presumably will be allocated only to the non-residents in accordance with their shares thereof ${ }^{6}$ resulting in a negative adjustment to their respective accounts. If the partnership terminates so that the non-residents cease to carry on business, the rule does not apply because they will not continue to be members of the partnership. In such a case, the termination of the partnership would trigger a deemed realization that is not subject to rollover treatment as the partnership would not be a Canadian partnership. ${ }^{17}$ The mechanics of the CCDE or Canadian oil and gas property expense accounts would nevertheless effectively give a rollover in the manner described earlier. As noted above, a non-resident partner appears to be able to sell his partnership interest without triggering the rule, presumably resulting in the realization by him of a capital gain. ${ }^{\text {is }}$

\section{Resolution 32: Transfer of Property to a Corporation}

That with respoct to diapositions of property made after December 11, 1979, the rules in section 85 of the Act not apply to

(a) dispositions of property to a corporation that is not a tarable Canadian corporation, and

(b) dispoaitions of Canadian resource properties by non-residents except with the concurrence of the Minister and upon such terms and conditions as he may specify.

\section{Resolution 26: Joint-exploration Corporation}

That payments made after December 11, 1979 to a joint exploration corporation by a shareholder corporation that is not a Canadian corporation that are used by the joint exploration corporation to acquire Canadian resource properties from the shareholder corporation may not be renounced in favour of the shareholder corporation.

In an attempt to achieve a complete closure of the conversion by non-residents of resource property dispositions to tax-free capital gain transactions, Resolution 32(b) denies rollover treatment to non-residents under subsection $85(1)$ of the federal Act where the transferred proporty is a Canadian resource property, unless the consent of the Department is first obtained. This is to prevent non-residents from transferring Canadian resource properties to a Canadian corporation on a rollover basis and then disposing of the shares in a transaction protected by a treaty provision such as Article VIII of the present Canada-U.S. convention. Unfortunately, the provision would prevent otherwise bona fide incorporations of a Canadian branch operation which may be done solely for business reasons or the compliance with governmental or other local requirements. The reference to Ministerial consent is clearly to allow incorporations of this type subject to such "terms and conditions" as may be specified.

The writer has been verbally advised by the Department of Finance that discussions are presently taking place between that department and the Rulings Division of the Department of National Revenue, the department to which it has been proposed

16. ITA. 9. 66.2(6).

17. Id., s. $98(3)$.

18. Article VIIl would not protect the capital gain as the existence of a Canadian permanent establishment in the partnership gives the partner a Canadian permanent establishment. See No. 630 v. M..V.R. 119591 22 Tax A.B.C. 91 . 
responsibility for the administration of this concept be delegated, with a view to outlining the types of "terms and conditions" which might be specified. Finance has indicated that, for example, the taxpayer may be required to satisfy National Revenue that there are good and valid business ressons for the incorporation and that resale of the shares is not contemplated at the time of the rollover. In addition, there may be a requirement of an undertaking from the non-resident to the effect that the non-resident will not dispose of the shares of the Canadian corporation for a period of $x$ number of years from the date of the rollover, except by way of assignment as security for a debt or obligation, without the consent of the Minister of National Revenue having been first obtained. At least one official of the Department of Finance has indicated that this bolding period may be as long as five years. There may also be a requirement that security be given in respect of any such undertaking required to be provided by the non-resident. Hopefully, Revenue will issue a policy statement by way of an interpretation bulletin or information circular by which further details of the types of terms and conditions they will require can be made public.

It must also be hoped that the time involved in obtaining the consent and the possible onerousness of the terms and conditions do not prove to be a hindrance to bone fide transactions.

There is a considerable amount of jurisprudence in Canadian tax law to allow the Departement of National Revenue to tar dispositions of shares of a corporation where the texpayer's intent is to indirectly dispose of fully taxable property through the transfer of such property to a corporation followed by the sale of the shares thereof. Accordingly, one may question the need to introduce provisions such as this which have the effect of also hindering non-offensive transactions. Apparently there is a fear by the Department of Finance that the juriaprudence may not be strong enough to remove protection provided by a treaty provision such as Article VIII, the concern being that the reference to "capital assets" in that provision" and the rules of interpretation of treaty provisions may override the domestic case law. The need for this proposal, however, may be obviated somewhat in the future as the more recent tax conventions Canada has negotiated allow it to tax dispositions of stock where the principal asset of the corporation is real property or natural resource properties..$^{20}$ Indeed, as noted below, the new Canada-U.S. tax convention will apparently contain such a provision. This being the case, presumably the $\mathrm{Ca}$ nadian jurisprudence would be applicable, although there may be an enforcement difficulty as the section 116 withholding requirements in respect of shares of a Canadian corporation (other than a public corporation) protect the fisc only in the amount of a capital gain and not a fully tarable gain on disposition of stock-in-trade.

Resolution 26 prevents the non-resident from achieving an effective rollover through the use of the joint exploration corporation rules. These rules allow such a corporation to renounce to a shareholder corporation the acquisition cost of a Canadian resource property purchased at fair market value from the shareholder corporation resulting in a wash transaction to the sharebolder corporation, assuming the amounts enter both sides of the same cumulative account - CCDE or cumulative Canadian oil and gas property expense account, as the case may be."1

\section{Resolution 35: Transfer of Corporate Residence}

That where at any time after December 11, 1979 a corporation incorporated in Canada ceases to be a resident of Canada or is continued in a foreign jurisdiction as if it had been incorporated under the laws of that jurisdiction,

(a) its taration year shall be deemed to end at that time,

19. Article VIIl of Canada-U.S. Tax Convention, supra.

20. See, e.g. Article XIIl of the, as yet unproclaimed, new Canada-U.S. treaty.

21. The December 11, 1979 Motion was harsher in that it would have disallowed the renunciation by a joint exploration corporation to a non-Canadian corporation of all CEE, CDE and Canadian oil and gas property ex. pense costs. 
(b) it shall be deemed not to be a Canadian corporation at any time after that time, and

(c) it shall be deemed to have wound up and distributed all of its property immediately before that time.

Subsection $48(1)$ of the federal Act provides that where a resident tarpayer has ceased at a particular time to be resident in Canada, he shall be deemed to have disposed, immediately before the particular time, of each property owned by him immediately prior to the time for proceeds of disposition equal to the fair market value of the property, and to have reacquired the property immediately thereafter at a cost equal to that same fair market value. The rule joes not apply to "taxable Canadian property" as taxable Canadian property is taxable by Canada on its disposition by a non-resident. Because of the words "For the purposes of this subdivision" which are found at the beginning of the subsection, being a reference to Subdivision c of the federal Act, the rule ap. pears to apply only to capital property. Accordingly, a corporation owning Canadian resource properties or foreign resource properties, which are not capital property, ${ }^{22}$ could cease to be a resident of Canada and not be subject to this "departure tax". Specifically, a number of schemes were developed whereby a Canadian corporation (often controlled outside of Canada) would be "continued" or "domesticated" under the laws of a foreign jurisdiction if the laws of the particular Canadian jurisdiction and the foreign jurisdiction so allowed. The State of Wyoming, U.S.A., is one foreign jurisdiction that allows corporations incorporated otherwise than under the Wyoming Business Corporations Act ${ }^{23}$ to become "domesticated" under and become subject to the laws of that Act as if the corporation had been incorporated thereunder. Apparently some of the offshore tax haven juriadictions were also prepared to accommodate taxpayers wishing to "continue" in such juriadictions, in some cases through the passage by the government of the particular offahore jurisdiction of private statutes, many of which were drafted by the tarpayer's Canadian counsel. Although such a continuation would not normally remove the corporation from the Canadian tax net in respect of resource property situated in Canada, ${ }^{24}$ resource properties situated outside Canada (foreign resource properties) would escape the confines of the Act if the tarpayer became non-resident.

As subsection 250(4) of the federal Act defines a corporation to be resident in Canada if it was incorporated in Canada after April 26, 1965 or was incorporated in Canada and carried on buainess in Canada at any time after that date, it was not entirely clear that a "continuation" would cause the corporation to cease to be a resident of Canada and therefore it was not clear that the "departure tax" would be applicable. Naturally, if the corporation failed to become a non-resident and continued to be resident in Canada, it would also continue to be subject to Canadian taxation. Article I of the present Canada-U.S. Tax Convention provides protection from Canadian taxation to an enterprise of the United States in respect of its industrial and commercial profits not allocable to a permanent establishment in Canada, but there was a concern that the continued corporation would not be a "Unitod States enterprise": the Protocol defines this to be an enterprise carried on in the United States by a corporation "created or organized in or under the laws of the United States of America". Quaere whether the continued corporation is "organized" under the laws of the particular U.S. jurisdiction."s

In any event, the proposal in Resolution 35 would operate to treat the corporation as if it had wound up and distributed all of its property immediately prior to the time it ceased to be a resident of Canada or continued in the foreign jurisdiction. Subject to the tax-free liquidation rules in subsection $88(1),{ }^{30}$ the deemed liquidation and the rule in

22. ITA, \&. 54(b)(ii); s. 39(1)(a)(ii).

23. Wyoming Stat. 1977, ss. 17.1.

24. A non-resident is subject to Canadian taxation on a disposition of a Canadian resuurce property: ITA is. 2(3). 248(1) (definition of "taxable Canadian property"), and 115(1)(a)(iii.1).

25. In the case of an individual. the treaty would appear to provide protection as a "Linited States enterprisealso includes an enterprise carried on in the United States by an individual resident in the Linited States.

26. These rules would appear to remain applicable where the corpuration is a taxable Canadian curpuration all of the stock of which is owned by another taxable Cenadian corpuration. as the Resulution deems the corpisa. 
subsection 69(5) of the federal Act would trigger an income realization to the corporation as if it had disposed of all of its property at fair market value. One would have thought that the deemed winding-up and distribution of properties would create a tax to the shareholders of the corporation, being a deemed dividend under subsection 84(2) of the federal Act equal to the excess of the value of the property distributed over the corporation's paid-up capital, and a capital gain or capital loss, pursuant to subparagraph $54(h)(x)$ of the Act equal to the difference between the paid-up capital of a share owned by a shareholder and his adjusted cost bese of that share. However, it is the writer's understanding that the shareholders will not be tared; instead, consideration is being given to assessing a tax to the corporation on its surplus as a substitution for the tax at the shareholder level. It is further understood that the deemed winding-up is to operate only for the purpose of measuring the tax payable. The corporation will not be considered to have actually wound-up and its continued actual existence will be recognized. Indeed, the Resolution provides that the corporation will thereafter be deemed not to be a Canadian corporation, the purpose here being to prevent the dividend tar credit and the intercorporate dividend rule in subsection $112(1)$ from arising in respect of dividends paid by the corporation after it has left Canada. In short, it appears as if, in substance, the Department of Finance is attempting to treat the continuance or cessation of residence as a liquidation and reincorporation with a tar on the surplus to be paid by the corporation. Hopefully, clearer rules will be provided in the legislation if this is the de. sired goal, including a rule to ensure a step-up in adjusted cost base at the shareholder level if tax on unrealized gains and on surplus is paid by the corporation.

\section{E. Resolution 22: Recaptured Depletion}

That the appropriate portion of all amounts in respect of services or property that became receivable by a tarpayer after December 11, 1979 and that would have reduced the tarpayer's earned depletion base, frontier exploration base or supplementary depletion base be included in income.

The calculations of a taxpayer's earned depletion base in section 1205 of the Income Tax Regulations ("the Regulations"), frontier exploration allowance in section 1207 of the Regulations and supplementary depletion base in section 1212 of the Regulations provide for the reduction of those respective accounts in certain cases on the disposition of certain properties. However, if the earned depletion base, frontier exploration base, or supplementary depletion base, as the case may be, has an unamortized balance of an amount that is less than the said reduction, the account is reduced to zero, but does not go negative nor is the amount by which the account would otherwise be negative included in income. Resolution 22 proposes to amend the Act 80 that what would otherwise be a negative balance resulting from such reductions will be included in income. In certain cases, there is no limit on the amount by which the particular account can be reduced and hence result in an income inclusion. For example, paragraph $1205(\mathrm{~g})$ of the Regulations provides that the earned depletion base is reduced by $33 \frac{13}{\%}$ of amounts that become receivable in respect of a property (other than a share of a Canadian resource property) the cost of which may reasonably be regarded as having been primarily an expenditure that was added to the earned depletion base. There is no limitation on this "recapture" to restrict it to the amount that was originally added to the earned depletion bese; if the amount receivable on the disposition of the property exceeds its cost, one-third of the excess will operate to reduce the depletion base or add to the taxpayer's income and does not represent a true "recapture" but rather an additional tax on the proceeds of disposition. 27

tion to cease to be a "Canadian corporation" at any time ofter it ceases to be a resident whereas the deemed liquidation and dissolution takes place immediately before the time it ceases to be resident.

27. See also, ITR, 8. $1207(2)(c)$. 


\section{F. Resolution 27: Earned Depletion of Successor Corporation}

That for the 1979 and subsequent taration years, a successor corporation or a second successor corporation bo entitiod to a deduction in respect of the earned depletion acquired from a predecessor corporation or successor corporation, ss the case may be, before making a deduction in respect of Cansdian exploration expenses.

At the present time, a principal-business corporation must deduct all claims for depletion allowance after claiming its deduction in respect of its cumulative Canadian exploration expense account." Because many principal-business corporations incur sufficient exploratory drilling costs in a year to effectively reduce their resource income to a relatively low amount, even to zero, and because earned depletion allowance can only be claimed against resource income after deduction of amounts in respect of the CCEE and CCDE pools, ${ }^{2}$ often such a corporation will not be entitled to claim earned depletion allowance. The result is that the unclaimed balance of the earned depletion base carries forward for use in subsequent taration years. The Resolution proposes to allow a principal-business corporation to deduct amounts in respect of the earned depletion base inherited from a second predecessor or first predecessor corporation prior to the claiming of its own Canadian exploration expenses. This is consistent with the provisions of the Act which allow a successor or socond successor corporation to deduct Canadian exploration expenses inherited from a first or second predecessor corporation prior to the deduction of its own exploration expenses."

\section{G. Resolution 39: Allocation of Partnership Income}

That for fiscal periods of partnership commencing after December 11, 1979, rules be introduced to ensure the reasonable allocation of income, losses or other amounts between non-arm's length partners.

Subsection 103(1) of the Act presently contains rules which allow the Department to reallocate income or loss of a partnership and deductions relating to activities of the partnership, such as CEE and CDE, where it can be shown that the principal reason for the existing agreement among the partners to share such amounts in certain specified proportions is the reduction or postponement of the tax that might otherwise be payable under the Act. The reallocations are to be done on the basis of reasonableness "having regard to all the circumstances" including the sharing of profits and losses from other sources. It was apparently felt that section 103 was not broed enough in that it only dealt with a particular partnership and Finance had apparently been advisod by lawyers in the Department of Justice that the language did not cover situations where income was disproportionately allocated by using a number of partnerships. The problem was considared to be a problem only in respect of non-arm's length situations partially because of the removal in Resolution 30 of the rule in subsection 74(5) of the federal Act relating to partnerships between spouses. However, it will be necessary to await the legislation before a better understanding of the proposal can be attained.

\section{H. Resolution 21: Capital Gain Strips}

That with respect to dispositions of property in most arm's longth and in certain non-arm's length circumstances, the Act be amended to ensure that

(a) where the dispoeition is a disposition under section 85 of the Act after December 11, 1979 by a tarpayor of property (othor than a share of the capital stock of a corporation connected with 02 a foreign affiliate of the tarpayes) and a corporation resident in Canada has recoived a dividend deductible under section 112 of the Act on a share that was issued as consideration for the property or that wes substituted or exchanged for such a share, or

(b) where the disposition is not a disposition reforred to in paragraph (a) and a corporation resident in Canada has after December 11, 1979 received a dividend deductible under section 112 of the Act one of the purposes of which (or in the case of a dividend received

28. TTA, s. 66.1(2).

29. ITR, 8. $1204(1)(0)$.

30. ITA, se. 66.1(2)(b); $66.1(4)$; $66.1(5)$. 
after April 21, 1980 under subsection 84(3) of the Act, one of the results of which) was to effect a significant reduction in a capital gain that is not attributable to income earned after 1971, the amount of the dividend shall except to the extent that it is subject to tax under Part IV of the Act be treated as a capital gain of the corporation in the year in which the dividend is 80 received.

Although not related solely to petroleum taxation, Resolution 21 will have application to certain corporate reorganizations or to sales of resource properties which are structured to reduce the gain thereon through the use of intercorporate dividends. While a detailed examination of the ovil sought to be cured and the medicine being prescribed is beyond the scope of this paper, a brief discussion may be useful.

Intercorporate dividends paid by a taxable Canadian corporation to a corporation resident in Canada, or paid by a corporation resident in Cansda which is not a tarable Canadian corporation to a corporation resident in Canada that controls the paying corporation, are not, generally, s" subject to Part I tax nor to Part IV tax where the recipient corporation is not a private corporation or, being a private corporation, is connected with the payer corporation.2 Under subsection 84(3) of the Act, a deemed dividend arises on the redemption, acquisition or cancellation by a resident corporation of any of its issued shares equal to the amount paid on the redemption, acquisition or cancellation less the paid-up capital of the shares. The intent is to treat all distributions by a corporation to its shareholders in excess of the paid-up capital of the corporation's stock as a distribution of earnings. Transactions were being structured, however, whereby sales of shares of a corporation to purchasers, which would otherwise result in a capital gain, were being structured as redemptions or purchases by the subject corporation of shares held by the vendor resulting in a deemed dividend to the vendor which, if a corporation, would be free of tax (assuming Part IV tax was not applicable). Subparagraph 54(h)(x) of the federal Act operated to reduce the proceeds of disposition and hence the capital gain. Because the amount of the dividend effectively represented the value of the shares redeemed or cancelled, often contributed or appraisal surplus would be created to satisfy dividend requirements of the relevant corporate law. Alternatively, appraisal surplus would be created and corporate dividends paid to the selling shareholder reducing the value of the company and the gain on sale of the stock. Yet another method involved the artificial increase of the corporation's paid-up capital and the creation of a deemed dividend under subsection 84(1) which had the effect of increasing the adjusted cost base of the stock by virtue of paragraph $53(1)(b)$ of the federal Act and hence reducing the amount of the gain. Assuming a taxpayer was satisfied that these types of transactions would not breach section 55 of the Act, consideration could have been given to transferring properties, including resource properties, to a corporation followed by the sale of shares thereof through one of the methods described above.

Section 55 of the Act presently reads as follows:

55. For the purposes of this subdivision, where the result of one or more sales, exchanges, declarations of trust, or other transactions of any kind whatover is that a taxpayer has disposed of property under circumstances such that he may reasonably be considered to have artificially or unduly

(a) reduced the amount of his gain from the disposition,

(b) created a loss from the disposition, or

(c) increased the amount of his loss from the disposition,

the taxpayer's gain or loss, as the case may be, from the disposition of the property shall be computed as if such reduction, creation or increase, as the case may be, had not occurred.

The Department of National Revenue warned on a number of occasions that it would apply section 55 where it considered the result of the transaction to be the conversion of

31. The exception relates to dividends paid on term preferred shares to certain taxpayers. See ITA 3. 248(1) (definition of "term preferred shares"), and ss. 112(2.1), 112(2.2), and 138(6).

32. ITA, \&. 112(1), Part IV. 
what would otherwise be a capital gain to a tar-free dividend. Its concerns related generally to two types of transactions:

(a) dispositions of shares of a corporation before, on, or subsequent to which the corporation or a corporation which acquires the shares pays or is deemed to pay a dividend free of Part IV tax which represents the capital gain which otherwise would have been realized on a sale of the shares; and

(b) sales by a corporation of capital property (other than shares) in an arm's length transaction in which proceeds of disposition are received as a dividend free of Part IV tax.

The Department's position on the first type of transaction was that a capital gain ought to be realized by the corporation receiving the tar-free dividend equal to the in. crease since 1971 in the value of the shares of the corporation being disposed of which value is reasonably attributable to unrealized or untared appreciation in goodwill and other assets. In transactions of the second type, it was the Department's position that a tarpayer should not be able to arrange its affairs in a manner which will result in the avoidance of tax on the sale of a capital property in an arm's length transaction. Accordingly, if as a result of a redemption or acquisition of the shares acquired in a section 85 rollover, amounts which otherwise would have been received as proceeds of disposition giving rise to a capital gain were instead received as a tar-free dividend, the Department's position was that there had been an undue reduction of a capital gain." Section 55 was relied upon as authority for the Department's position.

Section 55, however, applies only to prevent the artificial reduction of a capital gain: inventory or resource property dispositions structured to reduce gains thereon would not be caught by the section.

Resolution 21 appears intended to codify the position of the Department. The Resolution is, however, broader in scope than section 55 and a short analysis of the proposal is worthwhile.

(a) The proposal in paragraph (a) of the Resolution will apply to all dispositions of property under section 85 of the federal Act except dispositions of a share of a connected corporation. The rule will be that any dividends, deemed or actual, received by a corporation resident in Cansda (not necessarily the transferor under the section 85 rollover) that are deductible under section 112 of the federal Act on a share issued as consideration for the property disposed of or on a share substituted or exchanged for such a share will be treated as a capital gain unless the dividend is subject to Part IV tax. This is very broad in scope. For example, subject to the exemptions described in (c) below, the rule would apply to the disposition of a resource property for shares of a tarable Canadian corporation pursuant to the election in subsection $85(1)$ such that any dividends paid on the shares to the transferor would be tared as a capital gain. In the absence of an exemption to this rule, it may be necessary to ensure that dividends are paid on a second class of shares other than the class in respect of which shares were received on the transfer.

(b) Where the disposition is otherwise than as described above, the rule applies to dividends received by a corporation resident in Canada which are deductible under section 112 of the Act where one of the purposes of the dividend, or in the case of a deemed dividend under subsection 84(3) one of the results of which, is to effect a significant reduction in the capital gain that would otherwise result on the disposition. The dividend will be treated as a capital gain unless subject to Part IV tar or unless the dividend is attributable to income earned after 1971.

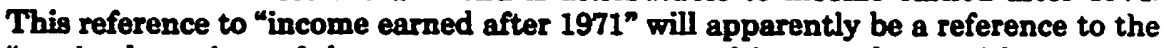
"retained earnings of the payer company computed in accordance with generally.

33. See Robertson. J.R. "An Update on a Departmental Perspective on Recent Developments in Federal Taration" (1979) 27 Canadian Tax Journal 428. 
accepted accounting principles to the extent such retained earnings are reflected for tar purposes".

(c) The Resolution indicates that these proposals will be applicable "in most arm's length and certain non-arm's length circumstances". The Supplementary Information indicates that these proposals will not affect "transactions in the course of bona fide corporate reorganizations, estate freezes and certain so-called 'butterfly' transactions". The writer has been advised that the exceptions to the proposals will be to the following effect:

(i) All non-arm's length transactions will be excepted except transactions between siblings, i.e. individuals (not corporations) who are brothers or sisters. Hence, a reorganization by a parent of its corporate group or a transfer of properties by a taxpayer to a non-arm's length corporation will not be subject to the rule.

(ii) A reorganization of the affairs of any person such that the interest of any arm's length party is not substantially altered.

(iii) A "butterfly" transaction which is to be a transaction where a corporation is divided into parts or a portion of its property is transferred to a new corporation and the indirect interests of the shareholders of the original company in the assets thereof before the transaction equals their indirect interests thereof after the transaction.

The Resolutions described above, as with all of the Resolutions in the April 21, 1980 Motion, are written in a broad or general form and an analysis of their true and complete effect cannot be made until after the draft language of the legislative amendments has been made public.

\section{THE ALBERTA CORPORATE INCOME TAX ACT}

On May 22, 1980, Bill 41, The Alberta Corporate Income Tax Act, ("the Alberta Act"), was enscted by the Legislative Assembly of Alberta. The Bill is the result of an announcement made in 1974 by the Alberta government that it proposed to opt out of the Alberta-Canada Tax Collection Agreement in respect of corporate income tax only. In a government paper issued on January 29, 1975, the Provincial Treasurer, The Honourable Gordon Miniely, indicated that one of the key components of the policy to control the rules under which corporate taxation is determined "is to encourage the growth of small Alberta-controlled, Alberta-resident business and agriculture" and the encouragement of the "diversification of Alberta's industry so that we are not as dependent on production of natural resources".

Bill 41 enacts a corporate income tax act that provides for the mechanism of administration and collection procedures and adopts the rules in the federal Act relating to calculation of income and tarable income. The business incentives described in Mr. Miniely's paper have not been incorporated into the legislation. Apparently, the government intends to introduce amendments to the Alberta Act in the next session which will contain the promised incentives.

A detailed analysis of the provisions of the Alberta Act is not the subject of this paper and in any event would be more appropriate after the next amendments thereto which will contain the incentives. The following summarizes the structure and general approach of the statute.

The Alberta Act comes into force on January 1, 1981 and applies to taxation years of a corporation beginning after December 31, 1980. The general tenor of the Alberta Act is to adopt the rules under the federal Act that are applicable in calculating income and taxable income for purposes of Part I of the federal Act. Section 5 of the Alberta Act is the general charging section which provides that a corporation that has a permanent establishment in Alberta at any time in a taxation year is subject to taxation under the 
Alberta Act. The computation of income is provided for in Part 2 of the Act. Section 6 contains the same set of rules for computation of income found in sections 3 and 4 of the federal Act. These rules provide that income is the aggregate of all income from sources within or without Canada including income from each business and property, plus the aggregate of net tarable capital gains over allowable capital losses minus the deductions provided for in Division 4 of Part 2, which incorporates the deductions-allowed by Subdivision e of Division B of Part I of the federal Act, minus the aggregate of losses from business or property. The provisions contained in Subdivisions b to $k$ of Division B of Part I of the federal Act are adopted to provide the rules for calculating business and property income, tarable capital gains and allowable capital losses, income from partnerships and truste, income from other sources and other deductions provided for in Subdivisions $d$ and e, respectively. These adopted rules also identify exempt items of income, and provide the rules for calculating income of a shareholder of a resident or non-resident corporation. The benefit rule in subsection $245(2)$ and the dividend stripping rule in subsection $247(1)$ are also specifically incorporated. ${ }^{3 \mathrm{~s}}$

Part 3 requires that income calculated as described above be reduced by deductions allowed under sections 110, 111, 112 and 113 of the federal Act in order to obtain "taxable income". As the calculation of tarable income includes the corporation's world wide income in the case of a corporation resident in Canada, and all Canadian source income in the case of a non-resident corporation, the taxable income is multiplied by the corporation's "Alberta allocation factor" which is the percentage of tarable income that is considered to be earned in the Province of Alberta determined in accordance with the rules provided in Part IV of the regulations to the federal Act. The product is referred to as the corporation's "amount taxable in Alberta" and the tax payable by the corporation is $11 \%$ of the amount tarable in Alberta. ${ }^{23}$ By referring to the rules in Part IV of the Regulations, the existing formula for the distribution of taxable income amongst provinces is retained.

It is understood that the rules under the federal Act will always be used to calculate income and taxable income and that the new business incentives to be introduced will, like the provisions discussed below, adjust only taxable income.

Where the corporation has amounts that are not deductible by virtue of paragraph 18(1)(m) of the federal Act or has an income inclusion by virtue of paragraph 12(1)(0) or subsection 69(6) or (7) of the federal Act, in respect of amounts such as Crown royalties on resource income, the corporation may deduct a "royalty tax deduction" from its taxable income before multiplying the difference by the Alberta allocation factor." The "royalty tax deduction" will replace the royalty tax rebate now found in section 8.4 of The Alberta Income Tax Act. The method of calculation remains unchanged except that the royalty tax deduction is a deduction from tarable income whereas the present royaity tax rebate is a deduction from tax otherwise payable.

Part 5 of the Alberta Act carries forward into the new Act the Alberta small business deduction now contained in section 8.7 of The Alberta Income Tax Act. The foreign tax credit and political contribution credits are also carried forward." A new Alberta Rental Investment Tax Credit, which provides for a tax credit equal to $5 \%$ of the capital cost of Alberta multiple unit residential buildings ("murbs") on a declining balance basis, is also provided for. ${ }^{\circ}$

Part 6 provides for the royalty tar credit or "small explorers' credit" now found in section 8.5 of The Alberta Income Tax Act. With some minor changes, the method of calculation is the same. However, new rules have been introduced to strengthen the ability

\footnotetext{
35. The Alberta Corporate Income Tax Act. S.A. 1980, c. 10, s. 13 [hereinafter referred to as "ACITAך].

36. Id., 3. 21.

37. Id., s. 20.

38. R.S.A. 1970, c. 182, as amended.

39. See, so. 5(3) and 8.6 of The Alberra Income Tax Act, id., and ss. 23 and 24 of the ACITA.

40. See, s. 25 of the ACITA.
} 
of the government to prevent artificial increases in the aggregate amount of a corporation's royalty tax credit through the use of multiple corporations or transactions lacking substantial business purposes other than increasing the aggregate amount of the royalty tax credit. There is also a requirement that the corporation retain and produce on demand true and complete copies of all documents relating to the determination of the amount on which its royalty tax credit is calculated, including any partnership agreements and the legal description of the particular resource property. The tert of these amendments is reproduced in the footnote below." Similar amendments have been made to The Alberta Income Tax Act which will apply to all taxpayers prior to 1981 and to individuals after 1980.

Any income tax convention between Canada and another jurisdiction which has the force of law in Canada and prevails over the federal Act to the extent of inconsistencies therewith, is deemed to apply for the purposes of the Alberta Act in the same manner as it applies for purposes of the federal Act. ${ }^{42}$

Election forms and other designations which are filed under the federal Act may, under subsection 2(6) of the Alberta Act, be filed with the Provincial Treasurer but need not be filed, in which case the Treasurer will accept the election or designation made under the federal Act and the late filing penalties under the federal Act do not apply.

The Provincial Treasurer's office has verbally indicated that it will consider itself bound by rulings given by the Rulings Division of the Department of National Revenue insofar as they affect provisions of the federal Act applicable to the Alberta Act but will also give rulings to taxpayers in respect of specific provisions of the Alberta Act.

The remainder of the Act sets out provisions relating to the filing of returns, assessments and reassessments of tax payable, penalties and interest, objections and appeals, and enforcement and procedural provisions. It is intended that a tarpayer file with his Alberta corporate tax return a copy of his return under the federal Act. Because the business incentives will constitute amendments to tarable income, the income calculations under the federal Act will not have to be redone on the Alberta form. The intention is to limit the paper work involved in connection with the Alberta return as much as possible.

\section{CANADA-U.S. INCOME TAX CONVENTION}

A press release was issued just prior to the time of writing announcing that agreement had been reached, after almost a decade of negotiation, on a new tax convention between Canada and the United States of America. At the time of writing, the only documentation available to the writer was a press release issued by the United States government

41. These new rules are contained in ss. 26(10), (11), (14) and (15) of the ACITA and are as follows:

26. (10) In computing the attributed Alberta royalty income of a corporation for the purpose of this Part, no amount shall be included that would, if included, artificially increase the attributed Alberta royalty income of that corporation.

(11) In order to qualify for a royalty tax credit under this section a corporation shall retain and produce on demand by the Treasurer a true and complete copy of all documents relating to its share of its attributed Alberta royalty income and its royalty tax credit, including any partnership agreements and the legal deacription of the property in respect of which the royalty tax credit is claimed.

(14) Where, in the opinion of the Treasurer, two or more corporations have at any time entered into one or more sales, exchanges, declarations of trust or othor transactions that

(a) lack any substantial business purpose, othor than increasing the aggregate amount of the royalty tax crodit that may be claimed under this section, or

(b) artifically increase the royalty tax credit that may be claimed under this section.

the Treasurer may direct that all of those corporations shall be deemed to be associated with each other.

(15) A direction mado under subsection (13) or (14)

(a) shall not apply to a cazation year of any corporation prior to the taxation year in which the direction is made, and

(b) may be revoked by the Treasurer and. if revoked. shall not apply to the taxation year in which the revocation occurs or to any subsequent taxation year. 
which summarizes, in two pages, the proposed amendments to the existing treaty. According to that release, the proposals include, among others, the following.

1. The rate of withholding tax on dividends will be reduced to $10 \%$ where there is a "direct investment" and retained at $15 \%$ in respect of "portfolio dividends". Apparently, dividends paid on a "direct investment" include those paid to a company owning $10 \%$ or more of the voting stock of the company paying the dividend. The branch tax on Canadian profits of a U.S. corporation will be limited to $10 \%$. Interest will generally be subject to a $15 \%$ withholding tax but "interest on credit sales will be exempt".

2. Royalties will be subject to withholding tax at a $10 \%$ rate. However, income from natural resource royalties will be fully taxable as business income in the country where the property on which the royalty is calculated is located. This is consistent with Resolution 44 of the April 21, 1980 Ways and Means Motion which, as described above, proposes to tax as business income Canadian royalty income of a non-resident who carries on a resource business in Canada.

3. The treatment of capital gains under the new convention will represent a significant change from the existing convention and apparently a special transitional rule is designed to avoid the disruption the change might have on existing investments. Under the existing treaty, Article VIII protects a resident of one of the contracting states from taxation by the other contracting state in respect of gains derived in that other state from the sale or exchange of capital assets, provided the taxpayer does not have a permanent establishment in the latter state. The intention now is to allow a country to tar any gain on the disposition of real property and the business assets of a permanent establishment which real property or permanent establishment are located in that country. It is also likely that the treaty will provide that each country can tax dispositions of shares of corporations holding real property in the other country. (In the new United Kingdom treaty, the rule extends to gains from the alienation of shares, other than shares quoted on a stock exchange, of companies which derive their value principally from immoveable property situated in the taxing state or gains from the alienation of interests in a partnership or trust the assets of which consist principally of immoveable property situated in that state.) The new convention will also deal with deemed dispositions under the federal Act which are not presently subject to treaty protection: apparently, a provision will be introduced to consider such deemed dispositions to be an alienation or other disposition the tarability of which by a particular country will be covered by the provisions of the treaty dealing with such alienations or dispositions.

4. The press release indicates that in the event a United States taxpayer incurs Canadian tax on certain transactions when there is no U.S. tax recognized, he will be given the right to recognize U.S. tax 80 as to be able to claim the foreign tax credit and obtain a stepped-up basis for U.S. tax purposes. Presumably, the reverse will be true for dispositions by Canedian taxpayers, which are subject to United States tax but not Canadian tax (such as a transaction subject to rollover treatment under subsection 85(1) of the federal Act but which does not qualify for rollover treatment under section 351 of the Internal Revenue Code because the $80 \%$ control test therein is not met).

5. "Canadian tar-free rollover provisions are generally leas liberal than the U.S. tax-free reorganization provisions. If a transaction would be tax-free in the United States, the Canadian Competent Authority is authorized to enter into an agreement providing for tax-free treatment in Canede and an appropriate carry-over of tax attributes."

6. The United States tax law was amended recently to disallow the deduction of convention expenses that are incurred outside the United States. Canada lobbied extensively to have itself excluded from this rule. The treaty proposes to do so, and the words of the press release are as follows: "Canada will be treated as part of the United States for purposes of the foreign convention rules". 


\section{OTHER RECENT DEVELOPMENTS}

There have been relatively few court cases heard during the past year which relate to oil and gas income taxation, but the Tax Appeal Board decision of Hannem v. M.N.R. ${ }^{\text {to }}$ is interesting in that it dealt with an attempt by a vendor taxpayer to claim a reserve on the sale of Canadian resource properties in return for a demand promissory note. Subsection 64(1) of the federal Act, as it read at the time of the particular transaction, provided for a reserve in respect of the proceeds of disposition of a Canadian resource property where the amount of the proceeds or a portion thereof were not "due" until a day after the end of the taxation year. Each subsequent year, the preceding year's reserve had to be included in income under subsection 59(2) of the federal Act and a new reserve could be claimed, again, based on the amount not "due" at the end of that subsequent year, subject to a rule that the reserve in any subsequent year could not exceed the reserve claimed in the year previous thereto.

Payments were made on the promissory note in the taxation year of the sale and the following two taxation years. The Board denied the claim for a reserve in each of the taxation year of the sale and the immediately following taxation year on the basis that a demand promissory note is a promissory note payable immediately and therefore no amount was "due" after the taxation years in question. Reference was made to Royal Bank v. Hogg"t and to Royal Bank of Canada v. Dwigans. "s

Subsection 64(1.1) operates in a manner similar to subsection 64(1) in respect of dispositions of Canadian resource properties after the 1974 amendments to the federal Act.

It is interesting to note the comments in Interpretation Bulletin IT-436 which was issued by the Department of National Revenue on August 6, 1979. The bulletin deals with situations where a vendor has accepted a promissory note either:"0

(a) as "conditional payment" of the unpaid balance of the purchase price, in which case the vendor is considered to have accepted the note as evidence of or security for the debt and is entitled to claim a reserve, or

(b) as "absolute payment" of the unpaid balance of the purchase price, in which case the vendor is considered to have accepted the note as full or actual payment of the debt, and as such accepts the note at the risk of the note being dishonoured with the only legal recourse being an action against the maker of the note for failure to honour the said note, in which case, the Department considers that no amount is "due" in respect of the disposition. The debt is considered to have been paid or satisfied by the receipt of the promissory note and, accordingly, no reserve is available.

Where a promissory note is payable on demand, the Department's position is the same as that of the Tax Appeal Board in that no amount is "due" after the end of the year and a reserve is not available. However, the Department indicates that where the demand promissory note provides that:

(a) demand for payment can only be made at certain times or upon the occurrence of some event; or

(b) demand for payment can be made at any time but payment is not due until the expiration of a specified time after demand has been made; or

(c) a combination of the above;

and the particular condition has not arisen at the end of the taxation year, the holder of the note is entitled to claim a reserve because, at the end of the taxation year, the note is not yet due. Accordingly, the problem in the Hannem decision can be solved by providing that the note is due "ten days after a demand"; if no demand has been made by

43. $|1980|$ C.T.C. 2089.

44. $\{19: 30 \mid$ 2. D.L.R. 488 .

45. $\{1933\}$ I. W.W.R. 6::2.

46. The Department s analysis wisuld appear to be supported by the case law. See Roryal Securities s. Montreal Trust Co. (1965) 59 D.L.R. 666. 
December 22 of a taration year that ends on December 31, the amount is not "due" at the end of the year.

The Bulletin contains a number of other positions of the Department in respect of promissory notes and the reserve provisions of the federal Act and should be referred to prior to any such transaction.

Another important policy decision of the Department of National Revenue in the past year is the Department's position in respect of "widespread farmin" arrangements. The tax treatment of farmout transactions dates back to committee debates in the House of Commons in November of 1962, wherein a "farmout" was described as follows:47

A common form of farm-out arrangement is an arrangement under which the holder of gas and oil rights agrees to assign a part of his intorest in the production from wells on the property to another person if the other person drills a well or wells to a specified depth, at his own expense. and the drilling is successful. (Italics added.)

Paragraph 11 of Interpretation Bulletin IT-125R2 contains a similar definition:

A form of farm-out agreement is one under which the owner of a resource property transfers a part interest in it to anothor person who undertakes to perform on the property farmout services, at his own expense, in the form of exploration and development expenses. (Italics added.)

The Bulletin is concerned with the tax treatment of the farmout to the farmor and not the farmee. However, the assessing policy of the Department for many years has been that a farmout is not only a non-tarable transaction to the farmor but also results in the farmee being treated as having incurred drilling costs and not as having incurred the cost of acquisition of a resource property. In other words, in relation to the current provisions of the federal Act, the farmee is considered to have incurred CEE or to have incurred CDE that is a drilling cost, as the case may be, but not to have incurred a cost of acquisition of a resource property which can only qualify as CDE.

Recently, however, the Department has indicated it will restrict this policy to situations where the drilling operations are undertaken on or in respect of property contiguous to the property that is conveyed by the farmor upon completion of the earning phase. In response to a question raised at the Canadian Tax Foundation Conference in Toronto in November of 1979, the Department commented as follows:

The wording in paragraph 11 of IT-125R2 reflects the understanding which has existed between the Dopartment and industry since at least 1962 when the question wes raised in the House of Commons.

The current problems in this area do not result from or constitute a reconsideration of our position. We are simply resisting attempts to have the concept extended to situations where the property received by the farmee bears no relationship to the property on which the exploration work is performed.

Quite frankly, we were unaware until very recently that 'widespread farmins' were being entered into, and we do not accept this concept.

In our opinion, the property in which an interest is being surrendered must be the property which will be potentially enhanced in value as a result of the exploration and development work.

It has been suggested that some arrangements will present a grey area; that is, it will be arguable that the properties received are 'enhanced' by the work performed elsewhere. To this we can only reply that, as in many other areas of the legislation, the facts will be determinative of the issue. (Italies added.)

The position of the Department now appears to be that, with respect to a widespread farmout, defined as indicated in the above quotation, the farmee will be treated as having acquired a Canadian resource property and will be considered, under Resolution 28, to have incurred a Canadian oil and gas property expense. The farmor will be treated, firstly, as having disposed of a Canadian resource property, resulting in a negative ad- 
justment to his CCDE or cumulative Canadian oil and gas property expense pool, as the case may be, equal to the proceeds of disposition of the property; and secondly, as having incurred the drilling costs for which he "paid" the farmee by conveying the interest in the resource property, resulting in a positive adjustment to his CCEE or CCDE pool, as the case may be and an addition of one-third of the costs to his earned depletion base. The "proceeds of disposition" of the resource property ought to equal the value of the drilling work done in return therefor - presumably the actual dollar amount paid to the drilling contractor." The bottom line to the farmor then is a reduction in one pool which will be at the least offset by an addition to another pool plus an addition to the earned depletion base." The farmee loses the earned depletion adjustment and has a $10 \%$ deduction instead of a $100 \%$ or $30 \%$ deduction, as the case may be. ${ }^{50}$

It is not clear as to whether or not the position of the Department is correct in respect of the farmee. Subsection 66(13) of the federal Act reads as follows:

Where a taxpayer has incurred an outlay or expense in respect of which a deduction from income is authorized under more than one provision of this section or section 66.1 or 66.2 , he is not entitled to make the deduction under more than one provision but is entitled to select the provision under which to make the deduction.

The Department has, however, advised the writer that in their view the provision is not applicable because the farmee has not incurred an expense that is both the acquisition cost of a resource property and a drilling cost but instead has incurred an outlay or expense deductible only under section 66.2 as the acquisition cost of a resource property. The subsection would also not completely solve the problem where the drilling costs are CDE: it does not ensure that an amount is added to the earned depletion base.

In Falconbridge Nickel Mines Ltd. v. M.N.R.s" the taxpayer was granted options to acquire shares of a new corporation and was further given the option to pay for the shares through the expenditure of money on diamond drilling and other exploration, development and mining work on certain mining claims owned by the new corporation. This was done and the issue was the deductibility of the expenses. At the time, there was no provision allowing the incurring of expenses for shares, but rather there was a provision which retroactively disallowed the deduction of expenses incurred for shares. ${ }^{32}$ The Exchequer Courts held that the taxpayer was unable to deduct the expenses because the taxpayer had been reimbursed by the issuance of the shares and, under the reasoning in Okalta Oils Limited v. M.N.R." had accordingly not "incurred" the exploration expenses. The Supreme Court, however, held that Falconbridge had incurred the expenses and had not been reimbursed and would have been entitled to the deduction but for the retroactive provision.

In fairness, the issue of whether the expenses were exploration expenses or costs of acquisition of shares was not discussed, the finding being just that the expenses were incurred by the taxpayer but were not deductible because they were incurred for stock. However, there were comments made in the Exchequer Court which are relevant as they did not form part of the decision of the Exchequer Court concerning the reimbursement,

48. The D'Auteuil Lumber Co. Ltd. v. M.N.R., supra n. 14.

49. The farmur may find himself in an improved position just in respect of the cumulative account adjustments. A farmor who has a $\$ 100$ balance in his Canadian oil and gas property expense poul at the end of a year would otherwise have a $\$ 10$ deduction. If, during the year, he enters into a "widespread farmout". and the drilling costs are CEE, if the drilling cost and the value of the resource property conveyed to the farmee equate at $\$ 100$, he will reduce the belance of his Cansdian vil and gas property expense pool to nil lassuming the resource property is a post.December 11. 1979 property). and add $\$ 100$ to his CCEE poul giving him a $\mathbf{\$ 1 0 0}$ deduction for the year instead of $\mathbf{\$ 1 0}$ in addition to the pusitive adjustment to his earned depletion base or \$33.33.

30. The Department's pusition in respect of non-widespread or conventiunal farmuuts is unchanged.

51. $\{1965]$ C.T.C. 514.

52. ITA, s. 83A(i).

53. $|1965|$ C.T.C. 82.

54. [1955) C.T.C. 39 . 
which was overturned by the Supreme Court. In particular the Exchequer Court indicated that where an exploration company agrees with the owner of property, for a consideration, to carry on an exploration program on its own behalf on property belonging to somebody else, the expenses would be incurred by the exploration company for purposes of the Act. Similarly, it noted that there was no requirement that the taxpayer by whom the expenses are incurred must incur them for exploration on his own property. Indeed, the Exchequer Court gave an example which would describe a conventional farmout:ss

If an exploration company carries on in an exploration programme on property belonging to somebody else under an agreement whereby, in the event of the programme having proved to be fruitful, the exploration company is to have certain rights in the future in respect of the property - e.g., the right to be a partner in the operation of the property or the right to purchase the property on specified terms - he would nevertheless appear to be entitled to make the deductions comtemplated by subsection (4).

The decision would appear to support the farmee's position in respect of a farmout, conventional or widespread, as there is no requirement in the current Act that the expenses be incurred on the farmee's own land. The decision may, however, have to be restricted clearly to its facts. Does it go 80 far as to qualify drilling expenses incurred by a farmee in return for the conveyance by the farmor of an office building? Would it allow the expenditure of foreign exploration and development expenses in return for shares of a corporation, Canadian or non-Canadian? At the least, in the case of exploratory drilling, the case ought to support the argument that the expenses are CEE and that the taxpayer can therefore elect under subsection 66(13) that the expenses be deductible under section 66.1 as CEE and not under section 66.2 as CDE.

The position of the farmor, however, may be undermined by any success of the farmoe in claiming his costs as drilling costs, as the farmor has surely disposed of a resource property and, assuming both taxpayers cannot incur the same expense, has not incurred any expenses to offset his proceeds of disposition. The concept of the farmee being agent of the farmor may be a possible interpretation depending on the wording of the agreement, although this was specifically found not to be the case in the Falconbridge decision.

In the meantime, the Department's position in respect of widespread farmins will result in some interesting and difficult interpretation problems. As indicated in the quotation above, there will be a "grey area" in applying the policy in determining whether or not a property will be "potentially enhanced in value" as a result of the exploration and development work. 